\title{
COPING WITH CLIMATE RISK IN AGRICULTURE NEEDS FARMER ORIENTED RESEARCH AND EXTENSION POLICIES
}

\author{
Kees Stigter \\ Agromet Vision - Groenestraat 13, 5314 AJ Bruchem, the Netherlands \& P.O. Box 16, 68208 Bondowoso, \\ Indonesia-e-mail <cjstigter@usa.net>
}

\begin{abstract}
The first necessary change for agrometeorology, in generally lower (external) input parts of agriculture in developing countries, is on research and extension. They have to refocus to preparedness for risks and uncertainties of local farming systems in need of support in four defined directions of prioritization, emphasis depending on the farming system concerned. These are (i) extreme events and their consequences caused by meteorological and climatological disasters on all time scales, including related aversion attempts; (ii) pests and diseases, including countervailing measures; (iii) trying to use beneficial climate and weather and (iv) applications of agrometeorological services. The second necessary change for such agrometeorology is participation of farmers in the establishment of agrometeorological services with well trained intermediaries in such undertakings as Climate Field Schools. The third necessary change is that agrometeorological services should be developed in such a way as to increase the resilience of farmers, in line with further and wider developments to be stimulated in rural areas. The most important and most insecure factors, however, will have to do with the socio-political allies to be supported to create - and keep everywhere - on a large scale the enabling environment. To sole cropping work, to which most response farming advisories were dedicated, if any, multiple cropping agrometeorological services have to be added. They should ideally belong to a new service environment in rural areas in progressing countries.
\end{abstract}

Key words: Climate Field Schools, agrometeorological services, participation, preparedness, resilience

\section{CONVIVER COM OS RISCOS CLIMÁTICOS NA AGRICULTURA REQUER PESQUISAS E POLÍTICAS DE EXTENSÃO VOLTADAS ÀS NECESSIDADES DOS PRODUTORES}

RESUMO: A primeira necessidade de mudança na agrometeorologia, em geral na agricultura dos países em desenvolvimento, é em pesquisa e extensão. Elas devem ser focadas na preparação dos sistemas agrícolas locais para lidar com os riscos e incertezas, de modo a dar suporte em quatro direções de prioridades, com sua ênfase dependendo do sistema agrícola considerado. Estas são: (i) eventos extremos e suas consequiências causadas por desastres meteorológicos e climatológicos em todas as escalas de tempo; (ii) pragas e doenças, incluindo medidas de compensação; (iii) procurar utilizar de forma benéfica as condições de clima e tempo; e (iv) aplicações dos serviços agrometeorológicos. A segunda mudança necessária para tal agrometeorologia é a participação dos produtores no estabelecimento dos serviços agrometeorológicos com intermediários bem treinados em empreendimentos tais como Escolas de Campo de Climatologia. A terceira mudança necessária é que os serviços agrometeorológicos deveriam ser desenvolvidos de tal forma a aumentar a resilência dos agricultores, de acordo com mudanças posteriores e mais amplas a serem estimuladas em áreas rurais. Os fatores mais importantes e inseguros terão, entretanto, que estar relacionados com os aliados sócio-políticos no sentido de estarem assessorados para criar - e manter em todo lugar - em uma ampla escala, o ambiente apto. Aos monocultivos, aos quais a maioria das recomendações agrícolas foram dedicadas, deve-se adicionar os serviços agrometeorológicos destinados aos cultivos múltiplos. Esses, idealmente, deveriam fazer parte de uma nova política ambiental em áreas rurais de países em desenvolvimento.

Palavras-chave: Escolas de Campo de Climatologia, serviços agrometeorológicos, participação, preparação, resiliência 


\section{INTRODUCTION}

To boost awareness on increasing climate variability and the elevating climate risk in agricultural production (and other uses of natural resources), most recently the new IPCC reports (WMO, 2007; RealClimate, 2007) and the work of Gore (2006), have scored very high.

In a first instance it will be the agrometeorologist's task here to develop understanding on the phenomena, impacts, actions, problems, solutions and policies related to priority extreme meteorological events that cause farmers and their local governments the largest difficulties in a region. In applied agrometeorology we must consider the causes of these phenomena known, as far as the basic sciences were able to explain their occurrence in the region. Detection of increasing climate variability is a matter of science (e.g. USDC/NOAA, 2007; WMO, 2007).

Awareness of elevating risks is a matter of extension (CPAS, 2004; Hansen \& Sivakumar, 2006; Stigter, 2006a; UNFCCC, 2007). Glantz (1987) was the first to propose to get away from considering climate conditions as drought as a boundary condition. He proposed to consider climatic factors only in the context of development constraints but Dhameja (2001) considered the development-disaster interconnection a lost awareness. For example Lassa (2006), followed up by Rathore \& Stigter (2007), reconnected the two, also in line with IPCC and other international trends (e.g. Hollister, 2007).

As observed in Stigter et al. (2003), obvious surface and subsurface drainage apart, for example onfarm storage of water in lowland and flat upland rice fields is the only example found of a solution of coping with floods in monocropping (Gomez, 2005). Floods originated by high rainfall cause soil erosion, but it is now generally accepted that also this is not simply a technical problem. The reason for a low success rate lies not only in the failure to solve certain technical aspects of the problem to full satisfaction, but also in the need to pay more attention to the social and economic roots of erosion crises (e.g. Roose, 1996; Kinama et al., 2007), so to development issues.

\section{Research and extension policies}

Solutions to problems due to extreme events are therefore to be found in a combination of agrometeorology with an understanding of the livelihood of farmers in which the agrometeorology has to be applied. This is where policy designs and policy preparations come into the picture (e.g. Baier, 2004). It is exactly this approach that WMO/CAgM (2006) has tried to promote in the last three decades by in- creasing the involvement of developing countries (Sivakumar et al., 2000; WMO, 2006). The same applies for example to FAO and UNEP (e.g. UNEP, 2000). One may talk about a policy divide, characterized by two distinct dimensions involving policy development and implementation, with some regions having strength in both and others still struggling in both and several in between (UNEP, 2003). Without solving this policy divide, also in agrometeorology, livelihood of farmers will not improve (e.g. Stigter, 2006a).

Socialization of agrometeorology means that policy matters of farmer oriented (i) action support systems (e.g. World Congress of Agroforestry, 2004; Stigter, 2006a), (ii) policy support options (e.g. Brown, 2003; Franzel et al., 2004) and (iii) capacity building strategies should get attention. Opportunities for agrometeorological services to farmers should be the guiding principle. For each of these three farmer oriented policy fields, we should prioritize agrometeorological aspects of how to cope operationally with risks and uncertainties from and preparedness for (i) extreme events and their consequences caused by meteorological and climatological disasters on all time scales, including related aversion attempts; (ii) pests and diseases, including countervailing measures; (iii) trying to use beneficial climate and weather and (iv) applications of agrometeorological services themselves.

Agrometeorological services are exemplified by agroclimatological characterization, design of microclimate management and manipulation, weather forecasting (including agrometeorological forecasting) and climate prediction, proposals of response farming, crop insurance and other advisories prepared for and by farmers in the previous three farmer oriented policy fields. For this to be possible, participative needs assessments should come first.

The available agrometeorological literature is most abundant for monocropping because it is the more general form of agricultural production in the western world, and often the more advanced form of production in other parts of the world, for which most research has been done. One may argue that this is particularly a form of industrialized agricultural production with commercial purposes already for a long time (e.g. Flynn, 1994). However, beyond the variability between "normal" seasons, unusual seasons are the next worries, particularly for the tropics with their more abundant disasters and consequential risks (Stigter, 2007a).

In developing countries with lower levels of input, and in their hilly and mountainous areas in particular, multiple cropping is a traditional method of intensive farming in their climates (Baldy \& Stigter, 1993, 
1997). It attempts optimal use, also with respect to risks of total crop failure in dry farming, of (associations of) local or other varieties of food and cash crops (including trees) proven to be suitable. This way there ideally should also be optimal use of land, water, solar radiation and other climatic factors, nutrients, labour and other socio-economic factors such as those related to round the year food availability for the farmer's household, marketability and prices.

Important from the point of view of agrometeorology is the question whether higher yields in a mixed, inter- or relay cropping system are due to a more complete use of the available resources over time or a more efficient use of the same resources in space. Because of sustainability in fragile or vulnerable systems, special attention is needed for responses in cases of actual limiting factors and of advantageous factors (services rendered) of one crop to the other (e.g. Stigter \& Baldy, 1993). Box 1 holds a successful example from Latin America, showing also what agrometeorology could do to improve such systems (Stigter, 2007b).

Box 1 (Stigter 2007b)

\section{INGA ALLEY CROPPING AS AN AGROMETEOROLOGICAL SERVICE TO SLASH AND BURN FARM-} ERS

According to Chris Geerling from the Working Group on Ecology and Development of the Netherlands Commission on International Nature Conservation, the wide ranges of (Low External Input) farming systems found in Africa - but the same applies to great parts of Latin America and Asia - is a reflection of the range of variation in the nature and the availability of the natural, economic and human resources, under widely varying geographical, climate, governance and political conditions. Geerling states that farming systems under these conditions mean playing the given deck of a whole series of low-value cards, with risk reduction as the main operative, rather than maximalisation of production.

Slash and burn agriculture contains several of such farming systems in which coping with risk reduction by farmers destroys forests. In such systems the soil quickly becomes infertile. In an example on the acid soils of the Costa Rican rain forest this was already the case after two years (Elkan, 2005, 2006). According to this author, based on research by the British tropical ecologist Mike Hands, alley cropping with Inga edulis is an agroforestry solution for such farmers in Costa Rica, Honduras and elsewhere that will make it possible to get into (more) sedentary farming as an alternative to slash and burn farming.

Agroforestry essentially has various agrometeorological components (e.g. Stigter, 1988). Alley cropping is an agroforestry system in which crops are grown in alleys formed by trees of which pruned biomass is used as mulch. This is incorporated into the soil for fertility and soil structure (water holding) improvement or spread over the soil as a surface mulch (Stigter, 1984). Surface mulches protect the soil from too strong solar radiation as well as too strong rainfall impacts. They also minimize weed growth by shade and smothering and provide nutrients according to their rates of decomposition (e.g. Stigter, 1984).

Alley cropping in semi-arid areas remained largely unsuccessful due to too low biomass accumulation and too high competition between crops and trees (e.g. Mungai et al., 1995, 2001). It may have there some benefits on sloping lands due to positive effects on runoff and soil loss (e.g. Kinama et al., 2007). In sub-humid to humid areas success with alley cropping on marginal soils is more likely but has also not been without difficulties (Carter, 1995).

In some alley cropping, shade of the trees is important against weeds and surface drying before their pruning. This is also the case in the Inga alley cropping design that therefore has a good set of agrometeorological aspects and may be treated as an agrometeorological service to the farmers concerned, at the same time providing the needed nutrients.

It is the merit of Hands' work that it first determined in a participatory approach with the Costa Rican farmers the problems of weed infestation and fast loss of productivity after slash and burn had taken place (Elkan, 2005, 2006). They were clearly in need of an alternative. It is another merit of Hands' work that he found the lack of phosphorus to be the main limiting soil factor due to fast leaching from the soil after slash and burn (Elkan, 2005, 2006). He then designed a system in which the conditions found in virgin tropical forests were mimicked: minimize weed growth - first by tree shading then by leaf mulches - and recycle nutrients, including phosphorus, through slow leaf decomposition, by using thick leaved nitrogen fixing trees providing sufficient biomass under the local climate conditions without too limiting competition.

After this system worked well with maize crops in Costa Rica, Honduran slash and burn farmers further developed the alley cropping of Inga with maize and beans and with pepper as well as vanilla. Moreover, the trees do provide a not unimportant amount of fuelwood. In Honduras an organic supplement of rock phosphate is used. The main remaining problem is the necessity to have seed orchards of Inga trees because the pruning for mulch prevents fruit setting. This is a seriously limiting factor to the speed with which the system can spread (Elkan, 2005, 2006).

What agrometeorology now could additionally contribute is a quantification of such systems in the way this was done by Mungai et al. (2000) in Kenya. Together with crop experiments this would ameliorate the design criteria and therefore improve the efficiency of such systems and the possibilities of transfer of their valuable basic merits to still other conditions. This is how design development of agrometeorological services of this kind is at its best, in collaboration with soil scientists, social scientists, botanists, agronomists and ecologists (WMO, 2006). 
The multiple cropping situations are much more complex than the monocropping ones and the same applies to the farming systems concerned and the agrometeorology to be used. Stigter \& Baldy (1989) distinguished and exemplified four types of multiple cropping systems with an ultimate distinction in the management of their biomass and the reasons behind this management. Multiple cropping of the first type is the purely sequential system in the same crop space or part of it. It of course most resembles monocropping. The second type are spatial and temporal intercropping systems without "active" services rendered from any intercrop to another crop. There are "passive" services on resource use in time and space. In the third type there are "active" services resulting in microclimatological (Stigter \& Baldy, 1991, 1993) and/or other advantages, for a sequential crop (carrying over effects) or a companion crop and/or the cropping environment. The fourth type are complex combinations of dominating and dominated components in space and time of highest intimacy (oases, homegardens).

This complexity has a large influence on the related farmer oriented extension that is needed while the farmer oriented research has also been much less for the farming systems concerned, while these appear essential for impacts (Franzel et al., 2004). This leads to the first necessary change we formulate for agrometeorology in generally lower (external) input parts of agriculture in developing countries. Research and extension have to refocus to preparedness for risks and uncertainties of local farming systems in need of support in the above defined four directions of prioritization, emphasis depending on the farming system concerned.

\section{Participation}

Stigter et al. (2007) argued the importance of paying attention to the enormous need for training of extension personnel at the intermediate level between makers of agrometeorological products and end users. For the establishment of agrometeorological services it has been proposed to train two kinds of intermediaries, of which the ones closest to extension would have to organize the participation of farmers.

In non-industrialized countries, training of extension intermediaries would go a long way in solving problems for various groups of all but the richest and best educated farmers. In recent operational developments this includes developing extension around the establishment of agrometeorological services. Particularly in all poorer countries, intermediaries should be the ones in direct contact with participating agricultural communities. Box 2 gives an example of an approach with Climate Field Schools in Indonesia in which this farmer participation is organized by the gov- ernment (Stigter, 2007a). This is the second necessary change we formulate for agrometeorology in generally lower (external) input parts of agriculture in developing countries. Participation of farmers in the establishment of agrometeorological services with well trained intermediaries in such undertakings as Climate Field Schools is a necessary condition for tackling the priority problems with agrometeorological components of the various farming systems.

\section{Preparedness}

Understanding on the phenomena, impacts, actions, problems, solutions and policies related to priority extreme meteorological events that cause farmers and their local governments the largest difficulties in multiple cropping in a region may, with the exception of the phenomena, be supposed to be different from those in monocropping by the same category of farmers. An issue to attend to appears to be what multiple cropping systems have as defence strategies to extreme meteorological events that are less efficient or not available in monocropping and what science can contribute to understanding and developing such strategies to better prepare farmers.

It was argued already quite some time ago that "funding organizations have too often failed to see the importance of multiple cropping micrometeorology in combating the on-farm damaging effects of meteorological hazards in low external input agricultural production in Africa and elsewhere (Stigter et al., 1991). Gommes (2004) argued similarly as to response farming. Recently WMO (2001), using proposals by Salinger et al. (2000), advocated as solutions institutionalized long term "weather advisories on farming, production and cropping systems, in accordance with the possibilities for change in the different farming communities", applying "to techniques of using inputs, soil conditions and planting densities, choices of cropping systems and varieties".

In addition, other response farming extension "through on-line current advisories, on time scales and in space scales as required" would be necessary, exemplified by "weather and climate forecasts and timely advises on farm operations such as sowing dates, weeding, fertilizing, spraying, integrated pest management, harvesting and drying" (Salinger et al., 2000; WMO, 2001). Irrigation is of course since long part of this range (e.g. Lomas \& Levin, 1979). However, where such knowledge is operational at all in agrometeorological services, it is mainly for monocropping (e.g. Stigter, 1999, 2006b), perhaps for sequential cropping (e.g. Brown, 2003), but it remains marginal for mixed (inter)cropping and relay (inter)cropping (Stigter \& Baldy, 1993), with the ex- 


\section{Box 2 (Stigter 2007a) \\ AN ACCOUNT OF VISITING THOSE INVOLVED IN CLIMATE FIELD SCHOOLS IN INDONESIA}

I was invited to visit at the end of February 2007 organizers, trainers and farmers involved in organizing the unique "Climate Field Schools" (CFSs) in Indramayu, Indonesia, $250 \mathrm{~km}$ east of Jakarta. Farmer groups took already twice part in such field schools, which are based on the experiences obtained with "Farmer Field Schools" developed in Integrated Pest Management (IPM) extension. The latter gave Indonesia some international fame over the last decade and application of such schools in coping with climate disasters appears a very good idea.

The CFSs were formulated by BMG (Agency for Meteorology and Geophysics, the Indonesian National Meteorological and Hydrological Services (NMHS)), IPB (University of Agriculture, Bogor), the Directorate General of Food Crops (Jakarta) and the Asian Disaster Preparedness Center (ADPC, Bangkok). The main general aim of such CFSs is to increase farmers' knowledge on the application of climate information in their decision making. The organizers in Indonesia, the Directorate of Crop Protection within the Directorate General of Food Crops in the Ministry of Agriculture, just finished the most recent training of trainers in the CFSs in the week of 12 - 19 April 2007.

The most important climate information input is for the time being a forecasting of the start of the rainy season, as made by the BMG. The basic extension aim of the present CFSs is to get the farmers familiar with a better determination of appropriate rice planting times under conditions of a changing climate. The local farmers told me that given the changing variabilities, this was for them an absolute priority. The following phases of the crop do not pose them comparable problems unless there is flooding or drought.

The experiments in 2005 and 2006 have given rise to larger scale applications that will this year be carried out with more than 200 CFSs in 19 provinces. These earlier trials also convinced farmers that this approach was better than what they traditionally applied prior to 2005. The role of the CFSs is that of the trainers involved being one class of intermediaries, between the forecasting products of BMG and the farmers, in an agrometeorological service act of joint determination of planting time. Farmers come with their own visual observations and next to BMGs' inputs there are those from one Automatic Weather Station (AWS) in Indramayu. The farmers act as field screeners.

Farmers being generally satisfied with the CFSs, the organizers and trainers see enough problems that have to be solved for improving the products at each level, that of BMG, that of training the trainers and that of advising the farmers. Firstly the BMG input information is general climate forecast information, not a product for the area or for farmers. Secondly, also planting time within the province is location specific and one AWS in insufficient. More ground truth, remote sensing and GIS applications could assist. Moreover, problems with the AWS and auxiliary equipment are rampant. Another type of intermediaries in the service of BMG should be able to look after such problems.

At the level of the trainers, the worries are mainly on sustainability of the present approach in the upscaling of CFSs and on reaching larger numbers of farmers that do not yet participate, without losing quality of information and feedback. New means of communication should be tried out, but cell phones are not yet suitable for a great majority of farmers. Rural radio would be a very fine medium but was not yet tried out. At the level of the farmers, organized communications between intermediaries and trainees and among farmers after the CFSs must also be tackled in the future. Personal communications are at present the main form of contact between farmers, comparable to what earlier Chinese research in poorer areas showed (Stigter et al., 2007).

The next issue would then be what other problems with agrometeorological components could in the course of time get attention in the view of these rice farmers. My conversations showed that these have to be found in the direction of water management in floods and droughts, water use efficiency and crop diversifications, also using AWS and other data more effectively.

ception of the long recognized but insufficient exploited protection functions of trees in agroforestry applications (e.g. Stigter, 1988). This brings the two necessary changes we formulated above together. To sole cropping work to which most response farming advisories were dedicated, if any, multiple cropping agrometeorology services have to be added by the extension intermediaries and the product intermediaries distinguished. Such products need to focus on the preparedness earlier formulated and the process as a whole needs local, public and international funding.

\section{Resilience}

Long experience of uncertainty about weather patterns has induced resilient farmers in rainfed subsistence economies to develop complex cultigen rep- ertoires and cultivar mixtures to ensure yields under all conditions. Such practice necessarily yields less than monocropping productive races under good conditions but yields better under the frequently occurring adverse conditions (for Africa, Blench \& Marriage, 1998). Replacing multiple crops with monocropping may raise demand for external inputs and increase pressure on the soil. Suitable socio-economic and policy environments to maintain and improve soil fertility may be lacking (UKDFID, 2002).

An important issue in this context is the observation of Blench (1999) that rainfall patchiness (dry spells as a serious short term drought pattern) and rainfall intensity are more important weather/climate forecast information to most farmers than the usually available forecasts, but that they are hardly available as such. 
After decades of monocropping using traditional slash and burn methods, a growing interest in intercropping and crop sequencing to overcome drought in Asia and the Pacific region has emerged (FAO, 2001a) and Box 1 holds an example for Latin America. In this context important factors of intercropping may be protection against extreme temperatures and surface soil drying by shading and mulching and against drop impact and leaching by rainfall interception and mulching (Box 1). Quantification of intercropping systems has a role to play in understanding such factors better for problem analyses and the design of improved solutions (Box 1). The same applies to the other (than dry spells) relatively shortterm extreme meteorological events in agricultural production such as floods and tropical storms, tornadoes \& strong winds (Rathore \& Stigter, 2007). Due to the meagre existing multiple cropping literature related to floods, collected by Stigter et al. (2003), green belts are known to reduce the impact of flooding. Beneficial vegetation in flood-hazard areas and/or upstream is preserved or improved by reforestation or by erosion and flood preventing the growth of grasses and trees/bushes on hill slopes and terrace raisers.

Multiple cropping literature on protection from strong winds and their effects is somewhat more abundant and has mainly to do with microclimate manipulation using forestry and non forest trees. An example of risks from wind damage provoked by changing multiple cropping food gardens into monocropping on Pacific islands is discussed in FAO (2001b). Review literature, including scientific aspects, is in Onyewotu et al. (2004) and Rathore \& Stigter (2007), while livelihood aspects may be found in Onyewotu et al. (2003). Such livelihood literature is again rare. Overall there has been little progress in reducing risk levels (Maunder \& Wiggins, 2007). This includes climatic risks in agriculture from extreme events in Africa (Stigter, 2006a) and even in India, with the exception of choices of more suitable varieties and plant population management (Sivakumar et al., 2005). In this same ODI series many facets of this general conclusion on risks are explained in detail as to pro-poor agricultural extension (Farrington et al., 2002), low external input agriculture (Tripp, 2006), poverty reduction strategies (Cabral, 2006), pro-poor agricultural policies (Dorward et al., 2004), decentralized natural resources management (Baumann \& Farrington, 2003), agricultural technology (Tripp, 2003) and poverty reduction, equity and climate change (Richards, 2003). The last subject Stigter (2006b) and Lemos \& Dilling (2007) dealt with more recently.
Agrometeorological services are not the only services necessary (see also for example Cadish et al., 2004). But they should belong to a new services climate. Presently, in economically progressing giant countries like China, India, Brazil, for many rural areas there are insufficient infrastructure, education, investment, self-administration and other general public and private services as a socio-economic environment suitable to quickly improve absorption of more and better weather services (Stigter, 2006d). In China there is the call for a New Countryside amidst more and more openly reported rural protest (e.g. Johnson, 2004). In India there is incessant rural turmoil in many areas and the successive governments fail to deliver because like in China and Brazil, geography continues to affect Indian regional development in countless subtle ways (Sachs, 2005). This brings us to the third necessary change we formulate for agrometeorology in poorer parts of agriculture in developing countries. Agrometeorological services should be developed in such a way as to increase the resilience of farmers in line with further and wider developments to be stimulated in rural areas. The most important and most insecure factors, however, will have to do with the socio-political allies to be supported to create - and keep everywhere - on a large scale the enabling environment.

\section{REFERENCES}

BAIER, W. Case studies of economically beneficial agrometeorological applications and services and other success stories in agrometeorology for policy matters: final report of the CAgM Expert Team. Geneva:WMO, 2004. 89p. (WMO/TD, 1202).

BALDY, C.; STIGTER, C.J. Agrometeorologie des cultures multiples en regions chaudes. Paris: INRA, 1993. 246p. (Collection "Du Labo au Terrain").

BALDY, C.; STIGTER, C.J. Agrometeorology of multiple cropping in warm climates. Oxford: IBH, 1997. 237p.

BAUMANN, P.; FARRINGTON, J. Decentralising natural resource management: lessons form local government reform in India. London: ODI, 2003. 4p. (Natural Resources Perspectives, 86).

BLENCH, R. Seasonal climate forecasting: who can use it and how should it be disseminated? London: ODI, 1999. 4p. (Natural Resources Perspectives, 47).

BLENCH, R.; MARRIAGE, Z. Climatic uncertainty and natural resource policy: what should the role of government be? London: ODI, 1998. 4p. (Natural Resources Perspectives, 31).

BROWN, L.R. Plan B: rescuing a planet under stress and a civilization in trouble. New York: W.W. Norton, 2003. Available at: http://www.earth-policy.org/Books/PB/PBch8_ss3.htm. Accessed 30 Sept. 2007.

CABRAL, L. Poverty reduction strategies and the rural productive sectors: what have we learnt, what else do we need to ask? London: ODI, 2006. 4p. (Natural Resources Perspectives, 100).

CADISH, G.; POULTON, C.; MUGENDI, D.; JAMA, B. Replenishing soil fertility in sub-saharan Africa: remaining challenges. World Congress of Agroforestry, 1., 2004. Abstracts. Available at: http:/ /conference.ifas.ufl.edu/wca/. Accessed 30 Sept. 2007. 
CARTER, J. Alley farming: have resource-poor farmers benefited? London: ODA, 1995. 4p. (Natural Resources Perspectives, 3).

CLIMATE PREDICTION APPLICATIONS SCIENCE WORKSHOP- CPAS, 2004. Available at: http://climateservices. coaps.fsu.edu/alpabstracts.doc. Accessed 30 Sept. 2007.

DHAMEJA, A. Droughts and floods: a case for "dying wisdom". In: SAHNI, P.; DHAMEJA, A.; MEDURY, U. (Ed.) Disaster mitigation, experiences and reflections. New Delhi: Prentice Hall, 2001. p.76-91.

DORWARD, A.; FAN, S.; KYDD, J.; LOFGREN, H.; MORRISON. J.; POULTON, C.; RAO, N.; SMITH, L.; TCHALE, H.; THORAT, S.; UREY, I.; WOBST, P. Rethinking agricultural policies for pro-poor growth. London: ODI, 2004. 4p. (Natural Resources Perspectives, 94).

ELKAN, D. The rainforest saver. 2005. Available at: http:// www.theecologist.co.uk/archive_detail.asp?content_id=424. Accessed 30 day Sept. 2007.

ELKAN, D. An alternative to slash and burn. LEISA: Magazine on Low External Input and Sustainable Agriculture, Special Issue, p.15-16, 2006.

FOOD AND AGRICULTURE ORGANIZATION. Developing farming systems and best practices for drought-prone áreas: report of the FAO Asia-Pacific conference on early warning, prevention, preparedness and management of disasters in food and agriculture. RAP 2001/14, Annex XIV, APDC/01/10, 2001a. Available at: http://www.fao.org/docrep/005/AC120E/ AC120e00.HTM. Accessed 30 Sept. 2007.

FOOD AND AGRICULTURE ORGANIZATION. Reducing agricultural vulnerability to storms, with special reference to farming systems and methods: report of the FAO Asia-Pacific conference on early warning, prevention, preparedness and management of disasters in food and agriculture, RAP 2001/14, Annex XI, APDC 01/07, 2001b. Available at: http://www.fao.org/ DOCREP/005/AC120E/AC120e12.htm. Accessed 30 Sept. 2007.

FARRINGTON, J.; CHRISTOPLOS, I.; KIDD, A.; BECKMAN, M.; CROMWELL, E. Creating a policy environment for pro-poor agricultural extension: the who? what? and how? London: ODI, 2002. 4p. (Natural Resources Perspectives, 80).

FLYNN, M.S. Weather services for agriculture. In: GRIFFITHS, J.F. (Ed.) Handbook of agricultural meteorology. Oxford: Oxford University Press, 1994. Chapter 25, p.256-263.

FRANZEL, S.; DENNING, G.L.; LILLESÿ, J-P.; MERCADO JUNIOR., B.; AUGUSTIN, B. Scaling up the impact of agroforestry: lessons from three sites in Africa and Asia. 2004. Available at: http://conference.ifas.ufl.edu/wca/. Accessed Sept. 2007.

GLANTZ, M.H. Drought and hunger in Africa: denying famine a future. Cambridge: Cambridge University Press, 1987. $457 \mathrm{p}$.

GOMEZ, B. Degradation of vegetation and agricultural productivity due to natural disasters and land use strategies to mitigate their impacts on agriculture, rangelands and forestry. In: SIVAKUMAR, M.V.K.; MOTHA, R.P.; DAS, H.P. (Ed.) Natural disasters and extreme events in agriculture. Berlin: Springer, 2005. 347p. (Chapter 15, p.259-276)

GOMMES, R. Applications of FAO agrometeorological software in response farming. Expert meeting on weather, climate and farmers, 2004. Available at: http://www.wamis.org/agm/meetings/ etwcf/Gommes/pps. Accessed 30 Sept. 2007.

GORE, A. An inconvenient truth, 2006. Available at: http:// www.climatecrisis.net/. Accessed 30 Sept. 2007.

HANSEN, J.W.; SIVAKUMAR, M.V.K. Advances in applying climate prediction to agriculture. Climate Research, v.33, p.1-122, 2006.

HOLLISTER, D. RI government moves to reduce disaster risks. The Jakarta Post, Jakarta, 10 September 2007, p.6.

JOHNSON, I. Wild grass: China's revolution from below. London: Penguin Books, 2004. 336p.
KINAMA, J.M.; STIGTER, C.J.; ONG, C.K.; NG'ANG'A, J.K.; GICHUKI, F.N. Contour hedgerows and grass strips for erosion and runoff control in semi-arid Kenya. Arid Land Research and Management, v.21, p.1-19, 2007.

LASSA, J. New direction needed for coping with disasters. The Jakarta Post, Jakarta, 16 January 2006, p.6.

LEMOS, M.C.; DILLING, L. Equity in forecasting climate: can science save the world's poor? Science and Public Policy, v.34, p.109-116, 2007.

LOMAS, J.; LEVIN, J. Irrigation. In: SEEMANN, J.; CHRIRKOV, Y.I.; LOMAS, J.; PRIMAULT, B. (Ed.) Agrometeorology. Berlin: Springer, 1979. p.217-264.

MAUNDER, N.; WIGGINS, S. Food security in Southern Africa: changing the trend? review of lessons learnt on recent responses to chronic and transitory hunger and vulnerability. London: ODI, 2007. 4p. (Natural Resources Perspectives,83).

MUNGAI, D.N. A microclimatological approach to understanding maize yield performance in alley cropping in the semi-arid areas of Machakos district, Kenya. In: STIGTER, C.J.; WANG'ATI, F.J.; NG'ANG'A, J.K.; MUNGAI, D.N. (Ed.) The TTMI-project and the "Picnic" model: an internal evaluation of approaches and results and of prospects for TTMI-Units. Wageningen: Wageningen Agricultural University, 1995. p.111-123.

MUNGAI, D.N.; STIGTER, C.J.; COULSON, C.L.; NG'ANG'A, J.K. Simply obtained global radiation, soil temperature and soil moisture in an alley cropping system in semi-arid Kenya. Theoretical and Applied Climatology, v.65, p.63-78, 2000.

MUNGAI, D.N.; STIGTER, C.J.; COULSON, C.L.; NG'ANG'A, J.K.; NETONDO, G.W.S.; UMAYA, G.O. Understanding yields in alley cropping maize (Zea Mays L.) and Cassia siamea (Lam.) under semi-arid conditions in Machakos, Eastern Kenya. Journal of Environmental Sciences, v.13, p.291298, 2001.

ONYEWOTU, L.; STIGTER, K.; ABDULlAHI, Y.; ARIYO, J. Shelterbelts and farmers' needs. LEISA: Magazine of Low External Input Sustainable Agriculture, v.19, p. 28-29, 2003.

ONYEWOTU, L.O.Z.; STIGTER, C.J.; OLADIPO, E.O.; OWONUBI, J.J. Air movement and its consequences around a multiple shelterbelt system under advective conditions in semiarid northern Nigeria. Theoretical and Applied Climatology, v.79, p.255-262, 2004.

RATHORE, L.S.; STIGTER, C.J. Challenges to coping strategies with agrometeorological risks and uncertainties: regional Perspectives; Asia. In: SIVAKUMAR, M.V.K.; MOTHA, R. (Ed.) Managing weather and climate risks in agriculture. Berlin: Springer, 2007. p.53-69.

REALCLIMATE. Climate science from climate scientists, 2007. Available at: http://www.realclimate.org/index.php/archives/ 2007/05/start-here/. Accessed 30 Sept. 2007.

RICHARDS, M. Poverty reduction, equity and climate change: challenges for global governance. London: ODI, 2003. 4p. (Natural Resources Perspectives, 106).

ROOSE, E. Land husbandry-components and strategy. Rome: FAO, 1996. (FAO Soils Bulletin, 70). Available at: http://www.fao.org./ docrep/T1765E/t1765e1a.htm. Accessed 30 Sept. 2007.

SACHS, J. The end of poverty: economic possibilities for our time. London: Penguin, 2005. 416p.

SALINGER, J.J.; STIGTER, C.J.; DAS, H.P. Agrometeorological adaptation strategies to increasing climate variability and climate change. Agricultural and Forest Meteorology, v.103, p.167184,2000 .

SIVAKUMAR, M.V.K.; STIGTER, C.J.; RIJKS, D.A.; OBASI, G.P Agrometeorology in the $21^{\text {st }}$ Century: needs and perspectives. Agricultural and Forest Meteorology, v.103, p.1-4, 2000.

SIVAKUMAR, M.V.K.; MOTHA, R.P.; DAS, H.P. Natural disasters and extreme events in agriculture: impacts and mitigation. Berlin: Springer, 2005. 347p.

STIGTER, C.J. Mulching as a traditional method of microclimate management. Archives of Meteorology, Geophysics and Bioclimatology B, v.35, p.147-154, 1984. 
STIGTER, C.J. Microclimate management and manipulation in agroforestry. In: WIERSUM, K.F. (Ed.) Viewpoints on agroforestry. 2ed. Wageningen: Wageningen Agricultural University, 1988. p.145-168.

STIGTER, C.J. The future of agrometeorology: perspectives in science and services. WMO-Bulletin, v.48, p.353-359, 1999.

STIGTER, C.J.; BALDY, C. Agrometeorology of multiple cropping systems: biomass management and the low external input African farmer. In: ICTP/SAPAM Workshop on the Applicability of Environmental Physics and Meteorology in Africa, 2., Triste, 1989. Proceedings. Trieste: ICTP/SAPAM, 1989. p. $1-13$

STIGTER, C.J.; BALDY, C. Microclimate and protection of the tropical agricultural environment. In: WOLF, J.N. (Ed.) Influence of the climate on the production of tropical crops. Stockholm: IFS/CTA, 1991. p.172-184.

STIGTER, C.J.; BALDY, C. Manipulation of the microclimate by intercropping: making the best of services rendered. In: SINOQUET, H.; CRUZ, P. (Ed.) Ecophysiology of tropical intercropping. Paris: INRA, 1993. p.29-44.

STIGTER, C.J.; BALDY, C.; COULSON, C.L.; OTHIENO, C.O.; MOHAMMED, A.E.; MUNGAI, D.N.; KAINKWA, R.M.R.; IBRAHIM, A.A. Meteorological hazards and the low external input farmer: some case studies. In: OGUNTOYINBO, J.S.; OMOTOSHO, J.B.; EKUWEM, E.E. (Ed.) Meteorological hazards and development. Lagos: Kola Okanlawon, 1991. p.59-64.

STIGTER, C.J.; DAS, H.P.; MURTHY, V.R.K. Beyond climate forecasting of flood disasters. In: Regional Training Course on Flood Risk Management (FRM-5) of the Asian Disaster Preparedness Center and the China Research Center on Flood and Drought Disaster Reduction. Beijing, 2003. CDROM.

STIGTER, C.J.; YING, T.; DAS, H.P.; ZHENG DAWEI; RIVERO VEGA, R.E.; NGUYEN VAN VIET; BAKHEIT, N.I.; ABDULLAHI, Y.M. Complying with farmers' conditions and needs using new weather and climate information approaches and technologies. In: SIVAKUMAR, M.V.K.; MOTHA, R. (Ed.) Managing weather and climate risk in agriculture. Berlin: Springer, 2007. p.171-190.

STIGTER, K. A contemporary history of a new approach to applied agrometeorology, 2006a. Available at: http:// www.agrometeorology.org/index.php?id=589 Accessed 30 Nov. 2007.

STIGTER, K. Agrometeorological services in various parts of the world, under conditions of a changing climate: Austin Bourke Memorial Lecture presented in the Royal Irish Academy, Dublin, 2006b. Available at: www.agrometeorology.org [Accounts of Operational Agrometeorology]. Accessed 30 Nov. 2007.

STIGTER, K. Equity climate for all, 2006c. Available at: http:// www.agrometeorology.org [Agromet Market Place]. Accessed 30 Nov. 2007.

STIGTER, K. Agrometeorological services, climate change and a new countryside. In: Fifty years of agrometeorology at CAU. Beijing: China Agricultural University. Presentations. 2006d. p.3-15.

STIGTER, K. An account of visiting those involved in climate field schools in Indonesia, 2007a. Available at: http:// www.agrometeorology.org, under [Accounts of Operational Agrometeorology]. Accessed 30 Nov. 2007.
STIGTER, K. Inga alley cropping as an agrometeorological service to slash and burn farmers, 2007b. Available at: http:// www.agrometeorology.org, [Accounts of Operational Agrometeorology]. Accessed 30 Nov. 2007.

TRIPP, R. The enabling environment for agricultural technology in sub-Saharan Africa and the potential role of donors. London: ODI, 2003. 4p. Natural Resources Perspectives, 84).

TRIPP, R. Is low external input technology contributing to sustainable agricultural development? London: ODI, 2006. 4p. Natural Resources Perspectives, 102).

UNITED KINGDOM. DEPARTMENT FOR INTERNATIONAL DEVELOPMENT - DFID. Soil fertility and nutrient management. 2002. Available at: http://www.keysheets.org/ green_7_soils.pdf. Accessed 30 Sept. 2007.

UNITED NATIONS ENVIRONMENT PROGRAMME UNEP. Managing fragile ecosystems: combating desertification and drought; Agenda 21, Chapter 12, Nairobi, UNEP, 2000. Available at: http:www.unep.org/Documents. Accessed 30 Sept. 2007.

UNITED NATIONS ENVIRONMENT PROGRAMME - UNEP. State of the environment and policy retrospective: 1972-2002; disasters. Nairobi, UNEP, 2003. p.270-300. Available at: http:/ /www.unep.org/geo/geo3/english/pdfs/chapter2-9_disasters.pdf. Accessed 30 Sept. 2007.

UNITED NATIONS FRAMEWORK CONVENTION ON CLIMATE CHANGE - UNFCCC. Assessing, predicting and managing current and future climate variability and extreme events, and implications for sustainable development: background paper, 2007. Available at:http://svrweb01.unfccc.int/files/ adaptation/sbsta_agenda_item_adaptation/application/pdf. Accessed 30 Sept. 2007.

U.S. DEPARTMENT OF COMMERCE. National Oceanic and Atmospheric Administration - NOAA. Observing climate variability and change, 2007. Available at: http:// www.oar. noaa.gov/climate/t_observing.html. Accessed 30 Sept. 2007.

WORLD Congress of Agroforestry, 1., Abstracts. Working together for sustainable land use systems, 2004. Available at: http:// conference.ifas.ufl.edu/wca/. Accessed 30 Sept. 2007.

WORLD METEOROLOGICAL ORGANIZATION - WMO. Climate, 2007. Available at: http://www.wmo.ch/pages/themes/ climate/index_en.html. Accessed 30 Sept. 2007.

WORLD METEOROLOGICAL ORGANIZATION - WMO. Intergovernmental Panel on Climate Change, 2007. Available at: http://www.ipcc.ch/. Accessed 30 Sept. 2007.

WORLD METEOROLOGICAL ORGANIZATION - WMO. Weather, climate and food security. Geneva: WMO, 2001. 24p. (WMO, 933).

WORLD METEOROLOGICAL ORGANIZATION - WMO. Commission for Agricultural Meteorology - CAgM. The first fifty years. Geneva: WMO, 2006. 44p. (WMO, 999).

Received January 07, 2008

Accepted June 13, 2008 